\title{
Establishment of a Selection System for the Site-Specific Incorporation of Unnatural Amino Acids into Protein
}

\author{
Dawood Salim Edan ${ }^{1,2}$, Inkyung Choi ${ }^{1}$, and Jungchan Park ${ }^{1,2 *}$ \\ ${ }^{1}$ Department of Bioscience and Biotechnology, Hankuk University of Foreign Studies, Yongin 449-791, Republic of Korea \\ ${ }^{2}$ Protein Research Center for Bio-Industry, Hankuk University of Foreign Studies, Yongin 449-791, Republic of Korea
}

\section{비천연 아미노산의 위치특이적 단백질 삽입을 위한 Amino Acyl-tRNA Synthetase 선별시스템 개발}

\author{
다우드 살림 이단 ${ }^{1,2} \cdot$ 최인경 ${ }^{1} \cdot$ 박중찬 $^{1,2 *}$ \\ ${ }^{1}$ 한국외국어대학교 생명공학과, ${ }^{2}$ 한국외국어대학교 산업용단백질연구센터 \\ (Received March 11, 2014 / Accepted March 19, 2014)
}

\begin{abstract}
Site-specific incorporation of unnatural amino acids (SSIUA) into protein can be achieved in vivo by coexpression of an orthogonal pair of suppressor tRNA and engineered aminoacyl-tRNA synthetase (ARS) that specifically ligates an unnatural amino acid to the suppressor tRNA. As a step to develop the SSIUA technique in Escherichia coli, here we established a new 2-step screening system that can be used for selecting an ARS variant(s) that ligates an unnatural amino acid to a suppressor tRNA. A positive selection system consists of chloramphenicol acetyl transferase gene containing an amber mutation at the $27^{\text {th }}$ residue, and efficiently concentrated amber suppressible ARS with a maximum enrichment factor of $9.0 \times 10^{5}$. On the other hand, a negative selection system was constructed by adding multiple amber codons in front of a lethal gene encoding the control of cell death $B$ toxin $(c c d B)$ which acts as an inhibitory protein of bacterial topoisomerase II. Amber suppression of $c c d B$ by an orthogonal pair of Saccharomyces cerevisiae tyrosyl-tRNA synthetase (TyrRS) and an amber suppressor tRNA significantly inhibits bacterial growth. This selection system was also able to efficiently remove amber suppressible ARS which could ligate natural amino acids to the suppressor tRNA. Thus, sequential combination of these two selection systems might be able to function as a powerful tool for selecting an ARS variant that specifically ligates an unnatural amino acid to the suppressor tRNA from an ARS mutant pool.
\end{abstract}

Keywords: control of cell death B (ccdB), selection system, unnatural amino acid incorporation

Site-specific incorporation of unnatural amino acids (SSIUA) that are different from the 20 canonical amino acids into proteins is a promising method to generate novel proteins with expanded biological, chemical, or physical properties. As a possible strategy to achieve in vivo SSIUA, an orthogonal pair of suppressor tRNA and engineered aminoacyl-tRNA synthetase (ARS), which ligates an unnatural amino acid to the suppressor tRNA, has been used in diverse organisms (Pastrnak et al., 2000; Kowal et al., 2001; Wang et al., 2001). The orthogonal suppressor tRNA should not be aminoacylated by any of the host endogenous ARS. Similarly, the orthogonal synthetase also should not aminoacylate any of the host endogenous tRNA, but efficiently charges the orthogonal suppressor

*For correspondence. E-mail: jpark@hufs.ac.kr; Tel.: +82-31-3304355; Fax: +82-31-330-4566
tRNA. Several known orthogonal ARS and tRNA pairs functioning in E. coli include the Methanococcus janaschii TyrRS/tRNA ${ }^{\mathrm{Tyr}}$ CUA pair (Wang et al., 2001), Saccharomyces cerevisiae TyrRS and a variant of $E$. coli initiator tRNA $\mathrm{tRNA}_{2}{ }^{\mathrm{fMet}}$ (fMam tRNA $_{\text {CUA }}$ ) pair (Lee and RajBhandary, 1991; Kowal et al., 2001), and $S$. cerevisiae PheRS/ tRNA ${ }^{\text {Phe }}$ CUA pair (Furter, 1998).

To alter the amino acid specificity of the orthogonal ARS so that it charges the orthogonal suppressor tRNA with a desired unnatural amino acid, a library of ARS mutants must be generated and screened (Wang et al., 2001, 2002, 2003; Chin et al., 2002; Santoro et al., 2002). A general in vivo selection strategy was developed that is based on the combination of a $\beta$ -lactamase-based positive selection followed by a barnase-base negative selection (Liu and Schultz, 1999). In the positive selection, suppression of the amber codon introduced at 
nonessential position(s) of the $\beta$-lactamase gene will allow cells to survive under positive selection pressure. In the presence of both natural and unnatural amino acids, survivors thus encode active synthetase charging the orthogonal suppressor tRNA with either a natural or an unnatural amino acid. In the negative selection, those synthetases with specificities for natural amino acids charge the orthogonal tRNA with a natural amino acid, resulting in suppression of an amber codon in the negative marker, barnase gene, and cell death. Since no unnatural amino acid is added to the medium, synthetases with specificities only for the unnatural amino acids will survive. Survivors passing both selection processes therefore must encode synthetases charging the orthogonal tRNA with an unnatural amino acid (Wang et al., 2001; Chin et al., 2002).

Although previously reported positive and negative selection systems have shown successful selection of genetically modified ARSs charging unnatural amino acids onto suppressor tRNAs from a mutant ARS library (Wang et al., 2001, 2002, 2003; Chin et al., 2002), amber codons introduced at the inside of a negative selection marker gene might have a possibility to cause false negative results due to loss of function by incorporation of amino acids different from the original residue. In addition, $\beta$-lactamase used as the positive selection marker (Liu and Schultz, 1999) is known to be secreted into medium where it can hydrolyse all the ampicillin, thereby which can cause survival of false positive cells.

For the purpose of reducing these possibilities, we have established a new 2-step selection system consisting of a chloramphenicol acetyltransferase (CAT)-based positive selection and a CcdB-based negative selection. The positive selection construct containing an amber codon at the $27^{\text {th }}$ residue of CAT gene was previously generated for amber suppression screening (Chow and RajBhandary, 1993). On the other hand, the negative selection construct was newly generated by adding multiple amber codons in front of N-terminal coding sequence of the control of cell death $\mathrm{B}$ toxin $(c c d B)$, of which product can be lethal to $E$. coli by inhibiting DNA-gyrase (topoisomerase II) function (Bernard and Couturier, 1992; Bernard et al., 1993). Coexpression of $S c$ TyrRS and amber suppressor fMam tRNA suppressed the amber codons and significantly inhibited bacterial growth. In combination with the positive selection, the newly generated negative selection construct may be able to effectively select an ARS variant that ligates an unnatural amino acid to the suppressor tRNA from an ARS mutant pool.

\section{Materials and Methods}

\section{E. coli strains, culture media, and plasmids}

E. coli strain TOP10 [F- $m c r \mathrm{~A} \Delta(m r r-h s d \mathrm{RMS}-m c r \mathrm{BC}) \Phi$
80lacZ $\Delta \mathrm{M} 15 \Delta$ lacX74 deo $\mathrm{R}$ recA1 araD139 $\Delta$ (ara-leu $) 7697$ gal $\mathrm{U}$ galK $\operatorname{rpsL}\left(\mathrm{Str}^{\mathrm{R}}\right)$ end $\mathrm{A} 1$ nup G] (Invitrogen) was used in this study. LB and GMML media supplemented with antibiotics $(100 \mu \mathrm{g} / \mathrm{ml}$ ampicillin and $20 \mu \mathrm{g} / \mathrm{ml}$ tetracyclin) and $0.2 \%$ arabinose (Sigma), if necessary, were used for bacterial culture. For positive selection assay, GMML medium was used. Concentrated $\mathrm{M} 9$ salt solution ( $5 \mathrm{X}$ ) was prepared by dissolving $30 \mathrm{~g} \mathrm{Na}_{2} \mathrm{HPO}_{4}, 15 \mathrm{~g} \mathrm{KH}_{2} \mathrm{PO}_{4}, 2.5 \mathrm{~g} \mathrm{NaCl}, 5 \mathrm{~g} \mathrm{NH}_{4} \mathrm{Cl}$ in $1 \mathrm{~L}$ deionized water solution. GMML medium was prepared by adding $2 \mathrm{mM} \mathrm{MgSO}_{4}, 0.1 \mathrm{mM} \mathrm{CaCl}, 0.4 \%$ glucose, $1 \%$ glycerol, $0.3 \mathrm{mM}$ Leu to $1 \mathrm{X}$ M9 salt solution.

Sc TyrRS expression vector pKK-TyrRS (pKK-TyrRS*9) and its empty vector pKK223-3 (Amersham) were described previously (Kowal et al., 2001). The pACamG encodes a CAT gene containing an amber mutation at the $27^{\text {th }}$ residue and a suppressor tRNA derived from mutant $E$. coli initiator tRNA gene trnfMT2:A71/T35A36/G72 (fMam tRNA CUA $_{\text {) (Chow and }}$ RajBhandary, 1993).

\section{Test for positive selection}

To test chloramphenicol resistance by amber suppression of CAT amber gene, pACamG was cotransformed into TOP10 with either pKK223-3 or pKK-TyrRS by electroporation at 1.8 $\mathrm{kV}$. Positive transformants were grown overnight in LB broth containing antibiotics ampicillin and tetracycline. After harvested by centrifugation, cells were resuspended in GMML medium and inoculated at 1/100 dilution into fresh GMML medium supplemented with $20 \mu \mathrm{g} / \mathrm{ml}$ tetracycline, $100 \mu \mathrm{g} / \mathrm{ml}$ ampicillin, and different concentrations of chloramphenicol from 0 to $200 \mu \mathrm{g} / \mathrm{ml}$. After $72 \mathrm{~h}$ culture at $37^{\circ} \mathrm{C}$, bacterial growth was estimated by measuring optical densities at $600 \mathrm{~nm}$.

To test selection efficiency of the positive selection plasmid pACamG, electro-competent TOP10 cells harboring pACamG were prepared and transformed with the same amount of plasmid DNA $(1 \mu \mathrm{g})$ from mixtures of pKK223.3 and pKK-TyrRS plasmids at a series of different ratios. After cell recovery, transformants were washed once with $500 \mu \mathrm{l}$ of GMML medium and cultured in fresh GMML medium until saturation (usually 24-48 h). Plasmid DNA was harvested from cultures by using standard methods (QIAGEN Plasmid Extraction kit) and analysed for the presence of TyrRS gene by restriction digestions with PstI and XmnI. DNA band intensity was measured by a densitometry program of a gel documentation system.

\section{Construction of a negative selection plasmid pAccdBam}

To generate an in vivo negative selection system, DNA fragment encoding CcdB (B subunit of control of cell death) and upstream linker region in pZero-2 (Invitorgen) was 
amplified with primers containing single or double amber codon(s) in front of $c c d B$ gene by PCR and cloned into pBAD/Myc-His A (Invitrogen) with $\mathrm{XhoI}$ and $K p n \mathrm{I}$ sites. The primer sequences used for this PCR are as follows: ccdBam-1, 5'-CACGCTCGAGAAGCCTATAGGTACGGCAGTTTAAG3'; ccdBam-2, 5'-CACGCTCGAGATAGCTATAGGTACGGC AGTTTAAG-3'; ccdB-R 5'-GGAGGTACCTCATTATATTCC CCAGAACATCAGG-3'. The positive clones were used as templates in order to amplify the DNA fragment encoding araC-araBADpromoter-ccdBamber-rrnB with primers PNF and PNR, of which sequences are 5'-CATCCCGGGAGCTGC ATGTGTCAGAGG-3' and 5'-ATCGTCATGAACTAGTGGA TTTGTCCTACTCAGGAGAGC-3', respectively. The amplified fragment was digested with $S m a \mathrm{I}$ and $B s p \mathrm{HI}$ and cloned into pACamG by replacing NcoI/XmnI fragment containing CAT amber gene, thereby generating pAccdBam-1 and -2 . The plasmid containing triple amber codons upstream of $c c d B$ coding sequence, pAccdBam-3, was created by site-directed mutation from pAccdBam-2 with primer ccdBam-3, 5'-CCAT GGATCCGAGCtAGAGATAGCTATAGG-3'. Site-directed mutation was performed by using QuikChange Multi site-directed mutagenesis kit (Stratagene). The mutagenesis processes were carried out by the direction of manufacturer's protocol and selected positive clones were then confirmed by DNA sequencing analysis.

\section{Amber suppression of $c c d B$ gene and effect of arabinose concentration}

To test whether amber suppression of $c c d B$ inhibits bacterial growth, the three pAccdBam plasmids were cotransformed into TOP10 with either pKK223-3 or pKK-TyrRS, and $50 \mu 1$ of 1/10-diluted transformant was grown on the LB plate containing $30 \mu \mathrm{g} / \mathrm{ml}$ tetracycline, $100 \mu \mathrm{g} / \mathrm{ml}$ ampicillin and with or without $0.2 \%$ arabinose. After incubation at $37^{\circ} \mathrm{C}$ for $30 \mathrm{~h}$, colony formation was observed. To test the effect of $c c d B$ amber suppression on bacterial growth in a liquid medium, a single clone selected from each plate was grown overnight in LB medium containing appropriate antibiotics without arabinose. The overnight seed culture was inoculated at $1 / 100$ dilution into LB broth media containing the same antibiotics. Bacterial growth was estimated by measuring an optical density at $600 \mathrm{~nm}$.

To determine the optimal concentration of arabinose for negative selection, Top10 cells harboring pABccdBam 3 and either pKK223-3 or pKK-TyrRS were inoculated at a cell density of approximately $6 \times 10^{6}$ cells $/ \mathrm{ml}$ into LB media containing $100 \mu \mathrm{g} / \mathrm{ml}$ of ampicillin and $30 \mu \mathrm{g} / \mathrm{ml}$ of tetracycline. After arabinose was added at concentrations ranging from $0.005 \%$ to $1 \%$, cultures were grown at $30^{\circ} \mathrm{C}$ for
$12 \mathrm{~h}$. Bacterial growth was determined by measuring optical density at $600 \mathrm{~nm}$.

Negative selection efficiency by $c c d B$ amber suppression

Electro-competent TOP10 cells harboring pAccdBam-3 were prepared and transformed with the same amount of plasmid DNA $(1 \mu \mathrm{g})$ from mixtures of pKK223-3 and pKK-TyrRS plasmids at a series of different ratios. The transformants were grown in LB media containing $30 \mu \mathrm{g} / \mathrm{ml}$ tetracycline, $100 \mu \mathrm{g} / \mathrm{ml}$ ampicillin, and $0.5 \%$ arabinose. Plasmid DNA was isolated from saturated cultures by using standard methods (QIAGEN Plasmid extraction kit) and analysed by restriction digestion with Pst $\mathrm{I}$ and $X m n \mathrm{I}$ as described previously.

\section{Results and Discussion}

\section{A general selection process for mutant ARSs that charge unnatural amino acids to a suppressor tRNA}

In this study, we established a new general selection method for genetically modified ARSs that ligate unnatural amino acids to an orthogonal tRNA. This selection method consists of the combination of a positive selection and followed by a negative selection (Fig. 1). The positive selection conferred by suppression of CAT amber mutation was carried out in the medium containing both natural and unnatural amino acids and yields ARS variants that charge either a natural or unnatural amino acid or both. Those ARS variants pass through the negative selection process which is conferred by amber suppression of a lethal toxin gene $c c d B$. Since the negative selection is performed in the absence of unnatural amino acids, ARS variants that charge natural amino acids will be dead due to the expression of $\mathrm{CcdB}$ protein and synthetases with specificities only for the unnatural amino acids will survive. Survivors passing both selection processes therefore must

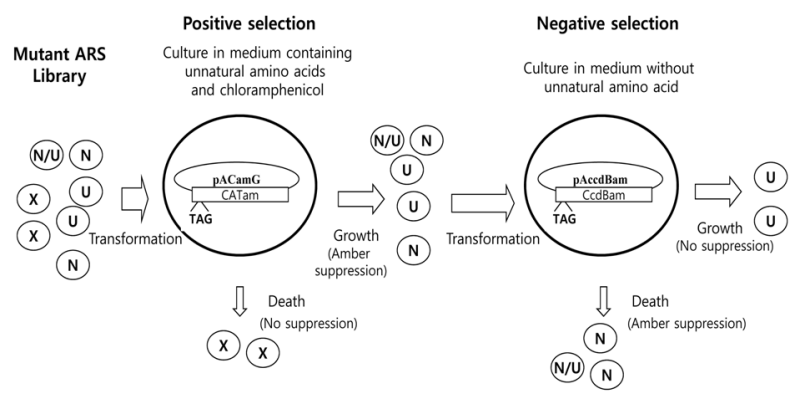

Fig. 1. A general selection process to isolate a mutant ARS(s) that ligates an unnatural amino acid to an orthogonal suppressor tRNA. Abbreviations: N, ARS that charges natural amino acid; U, ARS that charges unnatural amino acid; N/U, ARS that charges both natural and unnatural amino acid; $\mathrm{X}$, nonfunctional ARS. 
encode synthetases charging an unnatural amino acid to the orthogonal tRNA.

Positive selection: chloramphenicol resistance by CAT amber suppression and positive selection efficiency

To test the strength of CAT amber suppression activity by the orthogonal fMam tRNA/Sc TyrRS pair, pACamG was cotransformed into E. coli TOP10 with either pKK-TyrRS or an empty vector pKK223-3. Positive transformants were grown in GMML medium containing increasing concentrations of chloramphenicol. Growth was completely inhibited at low concentration of chloramphenicol $(20 \mu \mathrm{g} / \mathrm{ml})$ in cells harboring pACamG or pACamG plus pKK223-3, implying that the orthogonal fMam tRNA itself was not charged by any host-endogenous ARS. However, although there was gradual growth inhibition by chloramphenicol, cells harboring both pACamG and pKK-TyrRS could survive at high concentrations of chloramphenicol, indicating that coexpression of the orthogonal fMam tRNA and $S c$ TyrRS pair in E. coli resulted in aminoacylation of fMam tRNA and subsequently efficient CAT amber suppression (Fig. 2). Thus, pACamG construct can be used for positive selection at a good range of chloramphenicol concentrations $(20-100 \mu \mathrm{g} / \mathrm{ml})$.

To test efficiency of the positive selection, TOP10 competent cells harboring pACamG were transformed with a series of different combination ratios $\left(1: 10,1: 10^{2}, 1: 10^{3}, 1: 10^{4}\right.$, and $1: 10^{6}$ ) of two plamids, pKK-TyrRS and pKK223-3, and cultured in GMML medium containing chloramphenicol at concentrations of $20 \mu \mathrm{g} / \mathrm{ml}$ or $40 \mu \mathrm{g} / \mathrm{ml}$. Upon saturation of the cultures, plasmid DNA was purified and the ratios of pKK-TyrRS to pKK223-3 were determined by restriction digestion and analyzed by gel electrophoresis (Table 1).

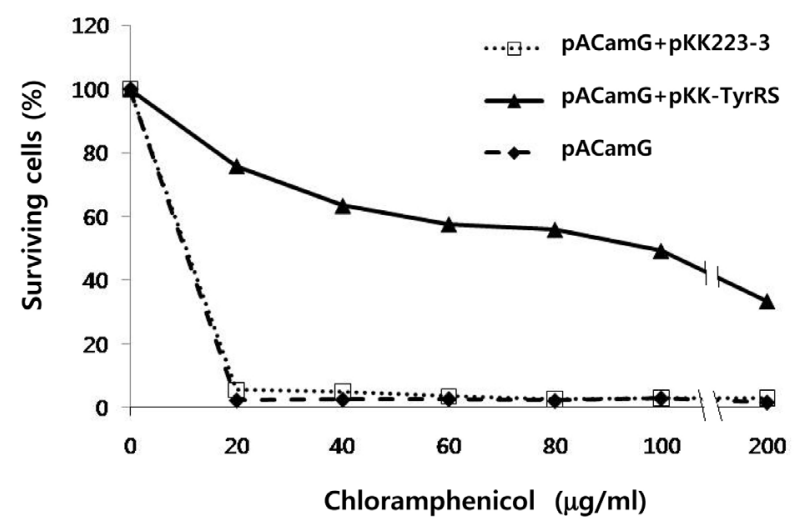

Fig. 2. Chloramphenicol resistance of the positive selection. Growth inhibition of E. coli transformed with pACamG and pKK-TyrRS or empty vector was tested in GMML medium containing of increasing amounts of chloramphenicol as indicated.
Table 1. Enrichment of amber suppressive plasmids (functional TyrRS) by Positive selection

\begin{tabular}{cccr}
\hline $\begin{array}{c}\text { Chloramphenicol } \\
(\mu \mathrm{g} / \mathrm{ml})\end{array}$ & $\begin{array}{c}\text { Starting ratio of } \\
\text { pKK-TyrRS/ } \\
\text { pKK223-2 }\end{array}$ & $\begin{array}{c}\text { Ending ratio of } \\
\text { pKK-TyrRS/ } \\
\text { pKK223-2 }\end{array}$ & $\begin{array}{c}\text { Enrichment } \\
\text { factor }\end{array}$ \\
\hline 20 & $1: 10$ & $1.7: 1$ & 17 \\
20 & $1: 10^{2}$ & $2: 1$ & 200 \\
20 & $1: 10^{3}$ & $1.7: 1$ & 1,700 \\
20 & $1: 10^{4}$ & $1.6: 1$ & 160,000 \\
20 & $1: 10^{6}$ & $0.7: 1$ & $7.1 \times 10^{5}$ \\
40 & $1: 10$ & $2: 1$ & 20 \\
40 & $1: 10^{2}$ & $3: 1$ & 300 \\
40 & $1: 10^{3}$ & $2.5: 1$ & 2,500 \\
40 & $1: 10^{4}$ & $2.9: 1$ & 290,000 \\
40 & $1: 10^{6}$ & $1.1: 1$ & $9 \times 10^{5}$ \\
\hline
\end{tabular}

Maximum enrichment resulted from media supplemented with $40 \mu \mathrm{g} / \mathrm{ml}$ of chloramphenicol. Under this condition, pKK-TyrRS was enriched by the factor of $9 \times 10^{5}$ (Table 1 ), which is better enrichment value than the previously described $\beta$-lactamasebased positive selection system (Liu and Schultz, 1999). Thus, this positive selection might be an effective method for the selection of functional synthetases from mixed populations of cells harboring functional or nonfunctional ARS expression plasmids. Significantly, the stringency of this positive selection may be tuned by varying the concentration of chloramphenicol added to the growth media.

CAT-based positive selection can provide more stable screening processes than the previously described $\beta$ -lactamase-based one (Liu and Schultz, 1999). The $\beta$-lactamase is well-known to be secreted gradually in the growth medium in which it can destroy ampicillin. Particularly, since the positive selection process is performed in a minimal growth medium containing an unnatural amino acid, bacterial culture time is usually longer than 2-3 days. In this case, the selection condition can be easily deteriorated by secreted $\beta$-lactamase and consequently result in growth of false positive cells that do not harbor a desired plasmid. On the other hand, CAT is not secreted to the growth medium and rescue of false positive cells is not possible in CAT-based positive selection.

Generation of the negative selection construct pAccdBam and its growth-inhibitory effects by amber suppression

To establish a negative selection system, $c c d B$ was chosen as an effector gene that will be lethal to bacteria after amber suppression. CcdB proteins has been shown both in vivo and in vitro to inhibit bacterial DNA-gyrase (topoisomerase II), an essential enzyme that catalyze the ATP-dependent negative supercoiling of DNA, by blocking its resealing of the double-strand nick in the DNA (Bernard and Couturier 1992; Bernard et al., 1993). Since the stringency of negative selection 
can be modulated by different numbers of amber codons in the effector gene, the $c c d B$ encoding DNA fragment containing single, double, or triple amber codon(s) in front of its coding sequence was cloned into $\mathrm{pBAD} / M y c$-His plasmid as described in 'Materials and Methods' and the cloned plasmids were designated as pAccdBam1, pAccdBam2, and pAccdBam3, respectively (Fig. 3A).

To test their possibility to act as a negative selection system, pAccdBam1, -2, and -3 plasmids were cotransformed into TOP10 with either pKK223-3 or pKK-TyrRS. Bacterial growth was tested on LB plate containing proper antibiotics with or without $0.2 \%$ arabinose (Fig. 3B). Among the three negative selection constructs, pAccdBam 1 and 2 strongly inhibited bacterial growth even without TyrRS expression, implicating that leaky expression of $\mathrm{CcdB}$ in those two clones was sufficient for growth inhibition. However, in case of pAccdBam 3 containing triple amber codons, cotransformation of pKK223-3 did not affect bacterial growth, whereas pKK-TyrRS cotransformation significantly inhibited bacterial growth on the culture plate containing $0.2 \%$ arabinose. The bacterial growth inhibition by TyrRS expression was not observed in the absence of arabinose, indicating that transcription of $c c d B$ gene under the control of $\operatorname{araBAD}$ promoter strictly depended on the inducer arabinose. The same results have been also observed in LB broth media containing $0.2 \%$ arabinose (Fig. 3C). The bacteria only harboring pAccdBam3 and pKK223-3 could continuously grow, whereas all other transformants were unable to grow. Taken together, these results indicate that pAccdBam $3 \mathrm{G}$ is capable of effectively discriminating the amber suppression from none suppressive conditions, and also provide a promising expectation as a negative selection system.

\section{Effect of arabinose concentration on the inhibition of bacterial growth by $c c d B$ amber suppression and negative selection efficiency}

The negative selection system is based on the suppression of triple amber codons in front of $c c d B$ coding sequence. However, since transcription of the $c c d B$ gene is under control of the araBAD promoter $\left(\mathrm{P}_{\mathrm{BAD}}\right)$ and the regulatory protein $\operatorname{araC}$, arabinose of appropriate concentration is necessary for expression of CcdB. To optimize the selection condition, $E$. coli Top10 bearing pAccdBam 3 and pKK-TyrRS or pKK223-3 was grown for $12 \mathrm{~h}$ in LB media containing different concentration of arabinose (Fig. 3D). Cells doubly transformed with pAccdBam3 and pKK223.3 (control vector) showed
(A)

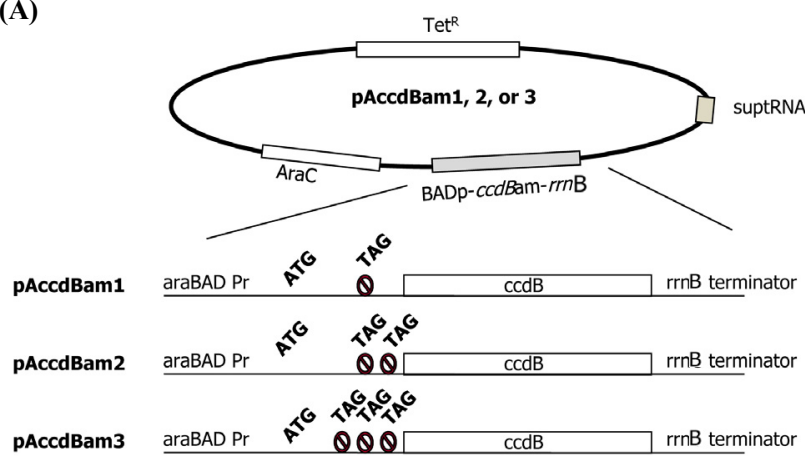

(C)

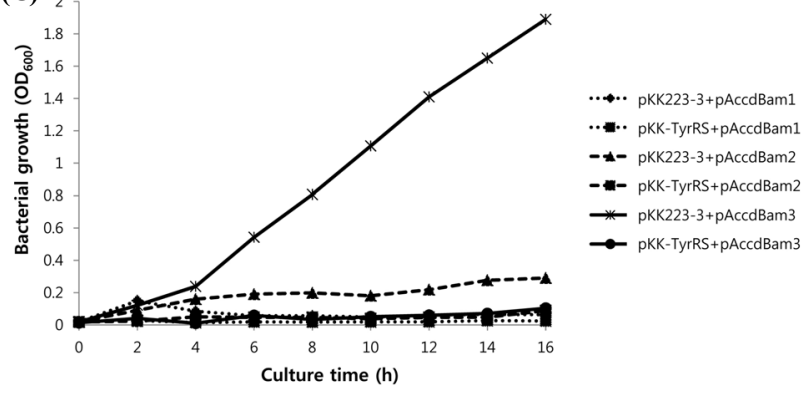

(B)

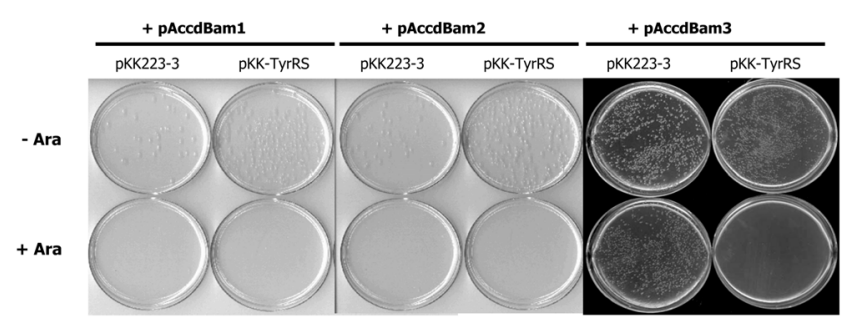

(D)

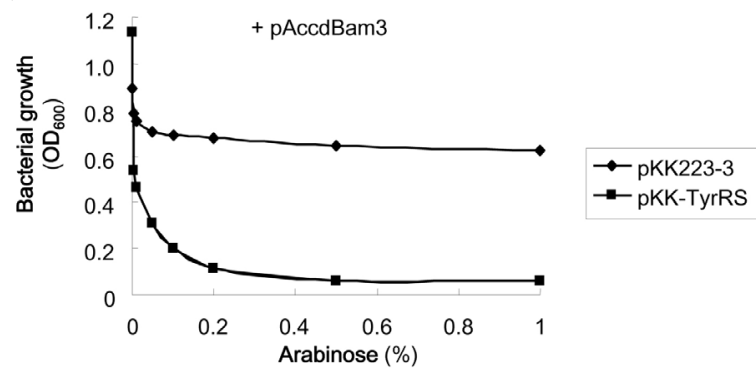

Fig. 3. Establishment of a negative selection system. (A) Diagram of pAccdBam1, 2, and 3 plasmids. Single, double, or triple amber codons were incorporated into upstream of $c c d B$ coding sequence. The amber-mutated $c c d B$ gene is under the control of the araBAD promoter. Thereby, its expression depends on the presence of arabinose in the medium. (B and C) Inhibition of bacterial growth by amber suppression of ccdB. One of the three pAccdBam plasmids was cotransformed to $E$. coli TOP10 with either pKK-TyrRS or an empty vector, and grown on the LB agar plates (B) and LB broth (C) containing arabinose as indicated. (D) Effect of arabinose concentration on the inhibition of bacterial growth. E. coli TOP10 containing pAccdBam3 and pKK-TyrRS or pKK223-3 was grown for $12 \mathrm{~h}$ in LB broth media containing different concentration of arabinose as indicated. 
Table 2. Enrichment of non-amber suppressive plasmids by the negative selection

\begin{tabular}{ccc}
\hline $\begin{array}{c}\text { Starting ratio of } \\
\text { pKK223-3 to } \\
\text { pKK-TyrRS }\end{array}$ & $\begin{array}{c}\text { Ending ratio of } \\
\text { pKK223-3 to } \\
\text { pKK-TyrRS }\end{array}$ & $\begin{array}{c}\text { Enrichment } \\
\text { factor }\end{array}$ \\
\hline $1: 10$ & $17: 1$ & 170 \\
$1: 10^{2}$ & $16: 1$ & 1,600 \\
$1: 10^{3}$ & $6.4: 1$ & $6.4 \times 10^{3}$ \\
$1: 10^{4}$ & $1: 1$ & $1.0 \times 10^{4}$ \\
$1: 10^{6}$ & $1: 17$ & $5.8 \times 10^{4}$ \\
\hline
\end{tabular}

slightly decreased the cell growth. On the other hand, in cells harboring both of pAccdBam3 and pKK-TyrRS, cell growth was dramatically decreased against increase of arabinose concentration, and the inhibitory effect by $c c d B$ amber suppression was almost saturated at $0.2 \%$ of arabinose in LB culture medium. These results indicate that arabinose is essential for induction of growth inhibition.

To assess negative selection efficiency of pAccdBam3, pKK223-3, and pKK-TyrRS were mixed in ratios of $1: 10$, $1: 10^{2}, 1: 10^{3}, 1: 10^{4}$, or $1: 10^{6}$, and transformed to TOP10 cells harboring pAccdBam3. After grown in LB broth media containing proper antibiotics and $0.5 \%$ arabinose, plasmid DNA was isolated from saturated culture. The ending ratios of pKK223-3 and pKK-TyrRS were determined by restriction digestion and densitometry of gel electrophoresis results (Table 2). Under these conditions, nonfunctional plasmid pKK223-3 was enriched by factors ranging from 170 to $5.8 \times 10^{4}$. As observed in the positive selection, higher level of enrichment was obtained with lower starting ratios of desired to undesired plasmids. These results demonstrate that the CcdB-based negative selection can effectively remove synthetases that ligate natural amino acid to the fMam tRNA and consequently select synthetases that are nonfunctional in the given culture medium where any unnatural amino acid is not included.

The previously reported barnase-based negative selection contains 2 or 3 amber codons in the internal coding sequence. Although the three positions (Gln-2, Asp-44, and Gly-65) are predicted to be non-essential for the barnase activity based on an analysis of its three-dimensional structure (Liu and Schultz, 1999), it is not proven by any experimental test. On the other hand, the CcdB-based negative selection contains tandem repeated 3 amber codons in front of the $c c d B$ coding sequence. An analysis of the three-dimensional structure of $\mathrm{CcdB}$ reveals that the N-terminal region is not essential for its killer activity (Loris et al., 1999). Therefore, we expect that the CcdB-based negative selection may be more permissive to the incorporation of diverse amino acids than the previously reported barnasebased one.

In conclusion, we generated a new 2-step screening system for selecting an ARS variant(s) that ligates an unnatural amino acid to a suppress tRNA. The CAT-based positive selection efficiently separated amber suppressible ARS from the mixture of unreactive ARS pool with a maximum enrichment factor of $9.0 \times 10^{5}$. The CcdB-based negative selection was also able to efficiently remove ARS that has specificity to natural amino acids. Thus, by sequential combination of these two selection systems, an ARS variant with specificity to an unnatural amino acid can be efficiently selected from an ARS mutant pool.

\section{적요}

생명체에서 비천연 아미노산을 단백질의 특정 위치에 삽입하 는 방법으로 orthogonal suppressor tRNA와 여기에 비천연 아미노 산을 특이적으로 결합시킬 수 있는 유전자 변형된 aminoacyl-tRNA synthetase (ARS)가 활용되고 있다. 이 기술개발을 위해서는 돌 연변이를 유발한 ARS library로부터 비천연 아미노산만을 특이 적으로 결합시킬 수 있는 변형된 $\mathrm{ARS}$ 를 탐색하기 위한 선별시 스템이 필요하다. 본 논문에서는 대장균에서 작용하는 2 단계로 구성된 새로운 선별시스템을 개발하였다. 먼저 양성선별 시스템 은 27번 잔기를 amber 코돈으로 치환한 Chloramphenicol acetyl transferase 유전자로 구성되어 있으며, 이유전자의 amber suppression 에 의해 chloramphenicol 배지에서 생존함에 따라 활성을 나타 내는 $\mathrm{ARS}$ 를 최고 $9.0 \times 10^{5}$ 배로 농축할 수 있었다. 반면 음성선 별 시스템은 대장균의 Topoisomerase II의 기능을 억제하는 단 백질을 암호화하는 control of cell death B $(c c d B)$ 유전자의 N말단 앞에 3 개의 amber 코돈을 삽입하여 제작하였다. 이 음성선 별 시스템을 가진 대장균에 orthogonal pair인 Saccharomyces cerevisiae tyrosyl-tRNA synthetase (Scc TyrRS)와 amber suppressor tRNA를 형질전환하면 amber suppression으로 $\mathrm{CcdB}$ 가 발현되어 대장균의 성장이 억제되는 것을 확인하였으 며, 천연 아미노산에 대한 특이성을 가진 $\mathrm{ARS}$ 를 효과적으로 제 거하는 것을 관찰하였다. 따라서, 양성선별 및 음성선별 시스템 을 순차적으로 거침으로써 무작위적으로 아미노산에 대한 특이 성을 변형시킨 $\mathrm{ARS}$ 라이브러리로부터 비천연 아미노산을 suppressor tRNA에 특이적으로 결합하는 유전자 변형 $\mathrm{ARS}$ 를 탐색하는데 유용하게 사용될 수 있을 것이다.

\section{Acknowledgements}

The authors thank Dr. RajBhandary for the gifts of pACamG and pKK-TyrRS. This research was supported by the grant of Gyeonggi Regional Research Center (GRRC) 2013-2014.

\section{References}

Bemard, P. and Couturier, M. 1992. Cell killing by the F plasmid CcdB protein involves poisoning of DNA-topoisomerase II complexes. $J$. Mol. Biol. 226, 735-745.

Bemard, P., Kézdy, K.E., Van Melderen, L., Steyaert, J., Wyns, L., Pato, 
M.L., Higgins, P.N., and Couturier, M. 1993. The F plasmid CcdB protein induces efficient ATP-dependent DNA cleavage by gyrase. J. Mol. Biol. 234, 534-541.

Chin, J.W., Martin, A.B., King, D.S., Wang, L., and Schultz, P.G. 2002. Addition of a photocrosslinking amino acid to the genetic code of Escherichia coli. Proc. Natl. Acad. Sci. USA 99, 11020-11024.

Chow, C.M. and RajBhandary, U.L. 1993. Saccharomyces cerevisiae cytoplasmic tyrosyl-tRNA synthetase gene. J. Biol. Chem. 268, 12855-12863.

Furter R. 1998. Expansion of the genetic code: site-directed $p$-fluorophenylalanine incorporation in Escherichia coli. Protein Sci. 7, 419426.

Kowal, A.K., Kohrer, C., and RahBhandary, U.L. 2001. Twenty-first aminoacyl-tRNA synthetase - suppressor tRNA pairs for possible use in site-specific incorporation of amino acid analogues into proteins in eukaryotes and in eubacteria. Proc. Natl. Acad. Sci. USA 98, 2268-2273.

Lee, C.P. and RahBhandary, U.L. 1991. Mutants of Escherichia coli initiator tRNA that suppress amber codons in Saccharomyces cerevisiae and are aminoacylated with tyrosine by yeast extracts. Proc. Natl. Acad. Sci. USA 88, 11378-11382.

Liu, D.R. and Schultz, P.G. 1999. Progress toward the evolution of an organism with an expanded genetic code. Proc. Natl. Acad. Sci. USA 96, 4780-4785.

Loris, R., Dao-Thi, M.H., Bahassi, E.M., Van Melderen, L., Poortmans, F., Liddington, R., Couturier, M., and Wyns, L. 1999. Crystal structure of CcdB, a topoisomerase poison from E. coli. J. Mol. Biol. 285, 1667-1677.

Pastmak, M., Magliery, T.J., and Schultz, P.G. 2000. A new orthogonal suppressor tRNA/aminoacyl-tRNA synthetase pair for evolving an organism with an expanded genetic code. Helv. Chim. Acta 83, 22772286.

Santoro, S.W., Wang, L., Herberich, B., King, D.S., and Schultz, P.G. 2002. An efficient system for the evolution of aminoacyl-tRNA synthetase specificity. Nat. Biotechnol. 20, 1044-1048.

Wang, L., Brock, A., Herberich, B., and Schultz, P.G. 2001. Expanding the genetic code of Escherichia coli. Science 292, 498-500.

Wang, L., Brock, A., and Schultz, P.G. 2002. Adding L-3-(2-naphthyl) alanine to the genetic code of E. coli. J. Am. Chem. Soc. 124, 18361837.

Wang, L., Zhang, Z., Brock, A., and Schultz, P.G. 2003. Addition of the keto functional group to the genetic code of Escherichia coli. Proc. Natl. Acad. Sci. USA 100, 56-61. 